Seminário de Pesquisa

Programa de Pós-Graduação

Design FAU USP

\title{
Pesquisa em design: uma análise dos espaços físicos de ensino das universidades que ofertam cursos de design de moda
}

\author{
Liliane da Silva Gonzaga, Maria Cecilia Loschiavo dos Santos
}

pesquisa qualitativa em design; design de moda; pedagogia superior de moda; espaço físico de ensino

Enquanto a palavra design está frequentemente vinculada ao fazer industrial, o profissional de moda parece se relacionar com aspectos criativos. No Brasil, apenas em 1990 a pesquisa em Design foi institucionalizada no ambiente acadêmico da pósgraduação stricto sensu. A pesquisa em design é um campo novo e ainda mais recente quando se analisa as pesquisas no campo

Doutorado

\section{Linha de Pesquisa \\ Teoria e História do Design}

\section{Liliane da Silva Gonzaga}

Doutoranda em Design, pelo Programa de Pós-Graduação em Design e mestre em Ciências em Têxtil e Moda, na Universidade de São Paulo. Especialização em Metodologia do Ensino Superior e EAD, pela FAEL - EAD. Graduação em Curso Superior de Tecnologia em Design de Moda, pela Faculdade Senac Pernambuco.

e-mail: lilianegonzaga@usp.br

Lattes: http://lattes.cnpq. br/5931072398189434

Orcid: https://orcid.org/00000003-3739-8019

\section{Maria Cecilia Loschiavo dos Santos}

É filósofa e professora titular de Design da Faculdade de Arquitetura e Urbanismo da Universidade de São Paulo. Ela obteve seu mestrado e seu doutorado em Filosofia. Sua pesquisa atual é sobre design de móveis modernos, moradores de rua e catadores de materiais recicláveis.

e-mail: closchia@usp.br

Lattes: http://lattes.cnpq. br/9875100117374731

Orcid: https://orcid.org/0000-

0001-9216-4421 do ensino superior de design de moda, estruturado por volta dos anos 1990, com a abertura dos mercados e o surgimento das semanas de moda. Há três tipos de pesquisas muito utilizadas no campo do design: estudo de caso, pesquisa-ação e design science research. Inicialmente, havia a ideia de que o presente estudo, parte integrante de pesquisa de doutorado em seu estágio inicial, se tratava de design science research. Todavia, foi observado nesse tipo de modalidade de pesquisa uma caraterística de prescrição de soluções para problemas, onde o pesquisador explora, descreve, explica o fenômeno e propõe intervenções. Com isso, reafirmase uma estrutura de investigação traçada em uma perspectiva fenomenológica e descritivo-observacional, já que a pesquisadora irá nas instituições de ensino superior que ofertam cursos de design de moda em busca de compreender como o estudante de moda se relaciona com o espaço físico das universidades; desse modo, haverá um detalhamento do fenômeno por meio de entrevistas semiestruturadas e questionários com docentes, estudantes e egressos; e contará também com impressões produzidas pela pesquisadora sobre aspectos dos projetos desenvolvidos pelos alunos. 


\title{
Design research: an analysis of the physical teaching spaces of universities that offer courses in fashion design
}

Liliane da Silva Gonzaga, Maria Cecilia Loschiavo dos Santos

\author{
qualitative research in design; fashion design; higher fashion \\ pedagogy; physical teaching space
}

While the word design is linked to industrial manufacturing, the fashion professional often seems to relate to creative aspects. In Brazil, it was only in 1990 that design research was institutionalised in the academic environment of the stricto sensu graduate program. Design research is a recent field, and even more when analysed the researches developed in the field of higher education in fashion design, structured around the 1990s together with the opening of markets and the appearance of fashion weeks. There are three types of research widely used in the field of design: case study, action research and design science research. Initially, it was held that the present study, an integral part of doctoral research in its initial stage, was about design science research. However, in this type of research modality, a characteristic of prescribing solutions to problems was observed, in which the researcher explores, describes, explains the phenomenon and proposes interventions. This reaffirms a research structure outlined in a phenomenological and descriptive-observational perspective, once that the researcher will go to higher education institutions that offer courses in fashion design in order to understand how the fashion student relates to the physical space of universities, in such way that this phenomenon can be detailed through semi-structured interviews and questionnaires with teachers, students and alumni; and will also feature impressions produced by the researcher on aspects of the projects developed by the students.

\section{Referências | References}

CHRISTO, D, A. \& CIPINIUK, A. 2009. Reflexões sobre epistemologia do design enfocando o design de moda. In: Anais Colóquio de Moda. Recife: Faculdade Boa Viagem.

DRESH, A.; LACERDA, D. P. \& MIGUEL, P. A. C. 2015. Uma análise distintiva entre o estudo de caso, a pesquisa-ação e a design science research. Revista Brasileira de Gestão de Negócios 17(56): 1116-1133.

PRADO, L. A. D. \& BRAGA, J. 2011. História da moda no Brasil: das influências às autoreferências. Barueri: Disal.

VAN DER LINDEN, J. C. S. 2010. Uma taxonomia para a pesquisa em design. In: Anais P\&D Design, $9^{\circ}$ Congresso Brasileiro de Pesquisa e Desenvolvimento em Design. São Paulo, Universidade Anhembi Morumbi.

\section{Maria Cecilia Loschiavo dos Santos}

She is a philosopher and ful professor of Design at the Faculty of Architecture and Urbanism, University of São Paulo. She got her MA and her Ph.D., in Philosophy, Aesthetics. Her current research is about modern furniture design, homelessness and recyclable material collectors.

e-mail: closchia@usp.br

Lattes: http://lattes.cnpq. br/9875100117374731

Orcid: https://orcid.org/00000001-9216-4421 